\title{
DIRECTOR INDEPENDENCE AND DERIVATIVE SUIT SETTLEMENTS
}

Although state corporation statutes vest the power to manage the affairs of a corporation in a board of directors, ${ }^{1}$ that power is often circumscribed when board members are named as defendants in a stockholder's derivative suit. ${ }^{2}$ In Clark v. Lomas \& Nettleton Financial Corp. ${ }^{3}$ the United States Court of Appeals for the Fifth Circuit held that a non-independent board of directors does not have the power to settle a stockholder's derivative suit. ${ }^{4}$ Rule $23.1^{5}$ of the Federal Rules of Civil Procedure requires court approval of settlements of derivative

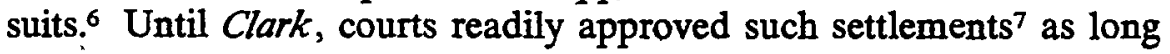
1980).

1. See, e.g., Cal. Corp. Code \& 300(a) (West 1977); Dez. Code ANn. tit. \&, \& 141(a) (Supp.

2. When a court allows a stockholder to maintain a derivative suit, see infra notes $63-68$ and accompanying text, the corporation is required to retain counsel independent of its board of directors. See, e.g., Rice v. Baron, 456 F. Supp. 1361 (S.D.N.Y. 1978); Messing v. FDI, Inc., 439 F. Supp. 776 (D.N.J. 1977); Cannon v. U.S. Acoustics Corp., 398 F. Supp. 209 (N.D. Ill. 1975), affd in relevant part, 532 F.2d 1118 (7th Cir. 1976); Lewis v. Shaffer Stores Co., 218 F. Supp. 238 (S.D.N.Y. 1963). See generally Note, Independent Representation For Corporate Defendants in Derivative Suits, 74 YALE L.J. 524 (1965). Furthermore, both legislatures and courts have limited the defenses a corporation may interpose on behalf of its board menbers implicated in a derivative suit. Both the Delaware and the California statutes deal with indemnification of a corporate agent for expenses incurred in successfully defending against claims. See Otis \& Co. v. Pennsylvania R.R., 57 F. Supp. 680 (E.D. Pa. 1944), affd, 155 F.2d 522 (3d Cir. 1946); see also Colan v. Monumental Corp., 524 F. Supp. I023 (N.D. Ill. 1981); Washington, Stockholders' Derivative Suits: The Company's Role and a Suggestion, 25 CoRnell L. Q. 361 (1940); Note, Defenses in Shareholders' Derivative Suits-Who May Raise Them, 66 HARv. L. Rev. 342 (1952).

3. 625 F.2d 49 (5th Cir. 1980), cert. denied, 450 U.S. 1029 (1981) (Clark II). The Fifth Circuit vacated and remanded the district court's approval of a derivative settlement proposal. 79 F.R.D. 641 (N.D. Tex. 1978) (Clark 1).

4. Clark II, 625 F.2d at 53-54. See infra notes $40-48$ and accompanying text.

5. Rule 23.1 provides:

In a derivative action brought by one or more shareholders . . . to enforce a right of a corporation.... the corporation ... having failed to enforce a right which inay properly be asserted by it, the complaint shall be verified and shall allege (1) that the plaintiff was a shareholder . . . at the time of the transaction of which he complains or that his share . . . devolved on him by operation of law, and (2) that the action is not a collusive one to confer jurisdiction on a court of the United States which it would not otherwise have. The complaint shall also allege with particularity the efforts, if any, made by the plaintiff to obtain the action he desires from the directors ... and the reasons for his failure to obtain the action or for not making the effort. The derivative action may not be maintained if it appears that the plaintiff does not fairly and adequately represent the imterests of the shareholders . . . similarly situated in enforcing the right of the corporation... . The action shall not be dismissed or compromised without the approval of the court, and notice of the proposed dismissal or compromise shall be given to shareholders ... in such manner as the court directs. (emphasis added)

6. This note concerns only settlement agreements that are brought before a court for approval pursuant to Rule 23.1. Whether a suit may be settled without judicial approval, as 
as the proposed agreement was not tainted by fraud or collusion and the terms constituted a "fair, adequate and reasonable" recovery for the corporation relative to the strengths and weaknesses of its legal claims. ${ }^{8}$ The Clark court's holding, however, precludes a nonindependent board from settling the suit even if the proposed terms are fair, adequate and reasonable. ${ }^{9}$

The Clark court reached its holding by relying on cases concerning excuse of the demand requirement, finding a "parity of reasoning" between those cases and settleinent cases. Rule 23.1 10 of the Federal Rules of Civil Procedure provides the starting point for the law concerning demand requirements. It requires a stockholder, before filing a derivative suit, ${ }^{11}$ to denand that the board of directors pursue redress of the claim on the corporation's behalf. ${ }^{12}$ Failure to make this

allowed in Wolf v. Barkes, 348 F.2d 994 (2d Cir.), cert. denied, 382 U.S. 941 (1965), is beyond the scope of this note. The Wolf holding has been criticized because it disregards the strong public policies favoring judicial supervision of the derivative settlement process, a process fraught with the potential for abuse. See, e.g., Comment, Compromise of Derivative Claims by a Corporation Without Court Approval, 52 VA. L. REv. 342 (1966).

7. Cases involving the settlement of derivative suits freely include citations to cases concerning settlements of class actions and bankruptcy proceedings, and vice versa. See, e.g., Clark II, 625 F.2d at 54. This note follows this practice. The Clark II court cited Miller v. Republic Nat'l Life Ins. Co., 559 F.2d 426 (5th Cir. 1977), a class action, which in turn cited Protective Comm. v. Anderson, 390 U.S. 414 (1968), a bankruptcy reorganization proceeding. 559 F.2d at 429. Protective Comm was also cited in Saylor v. Lindsley, 456 F.2d 896, 904 (2d Cir. 1972), a derivative suit. See also Burks v. Lasker, 441 U.S. 471, 485-86 n.16 (1979); Nêwman v. Stein, 464 F.2d 689, 692 n.6 (2d Cir.), cert. denied, 409 U.S. 1039 (1972).

8. See infra notes $94-120$ and accompanying text.

9. See infra text accompanying notes 99-103. See Clark II, G25 F.2d at 54.

10. For the text of rule 23.1, see supra note 5.

11. In a stockholder's derivative suit, the complaining stockholder is the party that litigates a corporation's alleged cause of action. Although the corporation on behalf of which a derivative suit is brought is a nominal defendant, it is in fact the real party in interest; any recovery from a derivative suit generally goes to the aggrieved corporation. See, eg., Pittston Co. v. Reeves, 263 F.2d 328 (7th Cir. 1959); Breswick \& Co. v. Briggs, 135 F. Supp. 397, 403 (S.D.N.Y. 1955); Haudek, The Settlement and Dismissal of Stockholders'Actions-Part I, 22 Sw. L.J. 763, 763-75 (1968).

Shareholders may also sue to recover for any direct injury they may have suffered as a result of a violation of their legal rights as shareholders. The distinetion between direct and derivative suits is often problematic. See Note, Distinguishing Between Direct and Derivative Shareholder Suits, 110 U. PA. L. REv. 1147 (1962). Although derivative suits may involve claims against persons or corporations unassociated with meinbers of a corporation's board of directors, this note examines only those derivative suits that allege claims against members of the corporation's board or against other entities in which board inembers have a pecuniary or other tangible imterest. In such cases, the board members stand in a "dual relation" to the transactions giving rise to the derivative suit. See infra note 16.

12. The demand may request redress outside of the judicial system, such as a change in corporate policy to prevent future wrongüoing. This note, however, is concerned only with demands that the board pursue judicial redress of the corporation's alleged legal claim. See generally .Note, The Demand and Standing Requirements in Stockholder Derivative Actions, $44 \mathrm{U}$. CHI. L. REv. 168 (1976) [hereinafter cited as Note, Demand and Standing Requirements]; Note, 
demand bars the stockholder from maintaining the suit ${ }^{13}$ unless the court excuses the demand requirement. ${ }^{14}$ The court will excuse the requirement when a sufficient number of members of a board of directors $^{15}$ are not imdependent of the transactions giving rise to the suit. ${ }^{16}$

This note examines the Clark opinion ${ }^{17}$ and reviews the underlying rationale of cases concerning excuse of the demand requirement. ${ }^{18}$ The note then examines the derivative suit settlement process $^{19}$ and the traditional legal standards for judicial approval of a proposed settlement. ${ }^{20}$ The note concludes that even though there are similarities between demand requirement cases and settlement cases, differences between the demand requirement and the settlement processes $^{21}$ indicate that the "parity of reasoning" relied on by the Clark court does not exist.

\section{CLARK V. LOMAS \& NETTLETON FINANCIAL CORP.}

The Clark case arose from the conduct of Lomas and Nettleton Financial Corporation (LNFC), NCS Coinputer Corporation, and Booth, Inc., concerning several mergers. In 1969, LNFC acquired control of NCS, allegedly to "disinantle" NCS for its own benefit.22 In

Demand on Directors and Shareholders as a Prerequisite to a Derivative Suit, 73 HARV. L. REV. 746 (1960) [hereinafter cited as Note, Demand on Directors].

13. See infra notes 56-58 and accompanying text. The Supreme Court has characterized the stockholder derivative suit as two causes of action: it is an action against the corporation for 'refusing to take those steps demanded by the stockholder, and it is an action against those whom the stockholder alleges are responsible for the violation of the corporation's legal rights. See Ross v. Bernhard, 396 U.S. 531, 538 (1970); Hawes v. Oakland, 104 U.S. 450, $452-53$ (1881); Note, The Business Judgment Rule in Derivative Suits Against Directors, 65 . CORNELL L. REv. 600, 603-08 (1980) [hereinafter cited as Note, Business Judgment Rule]; Note, Demand on Directors, supra note 12 at 748 .

14. See infra notes $65-68$ and accompanying text.

15. See infra note 68 and accompanying text.

16. In United Copper Sec. Co. v. Amalgamated Copper Co., 244 U.S. 261 (1917), the Supreme Court stated:

[w] hether or not a corporation shall seek to enforce in the courts a cause of action for damages is, like other business questions, ordinarily a matter of internal management and is left to the discretion of the directors, in the absence of instruction by vote of the stockholders. Courts interfere seldom to control such discretion intra vires the corporation, except where the directors are guilty of misconduct equivalent to a breach of trust, or where they stund in a dual relation which prevents an unprejudiced exercise of judge. ment....

Id at 263-64 (emphasis added).

17. See infra notes $22-53$ and acconipanying text.

18. See infra notes $70-80$ and accompanying text.

19. See infra notes 81-120 and accompanying text.

20. See infra notes $95-120$ and accompanying text.

21. See infra note 121-140 and accompanying text.

22. Clark $I I, 625$ F.2d at 50 . 
1972, LNFC agreed with Booth, Inc. that Booth would merge with NCS; NCS survived the merger, but operated under the Booth name. ${ }^{23}$ Following this merger, former shareholders of NCS filed suit, both in a direct action in their personal capacity and in a derivative action on behalf of Booth, ${ }^{24}$ alleging that LNFC had committed securities laws violations prior to the NCS-Booth inerger. ${ }^{25}$ The plaimtiffs also attacked this merger in an amended coinplamt.

Three years later, the plaintiffs agaim successfully sought leave to amend their complamt, this time in order to name several additional defendants, including Jack Booth, who was then president, director, and the largest stockholder of Booth, Inc. ${ }^{26}$ Prior to this amendment of the complaimt, Booth, Inc. had not opposed the suit; it had only answered that the court should award it any recovery the suit might produce. ${ }^{27}$ When confronted with the plaimtiffs attempt to join the corporation's largest stockholder, however, the corporation's board of directors began actively to oppose the suit. ${ }^{28}$

At the request of the district court, the plaintiffs, the defendants, and the corporate counsel of Booth, Inc. began negotiations to settle both the derivative and the direct claims. ${ }^{29}$ When the negotiators failed to reach an agreement to settle all of the claims, the district court recommended that the parties negotiate to settle only the derivative claims. ${ }^{30}$ The plaintiffs refused to participate im such negotiations. ${ }^{31}$

23. Id at 51 .

24. The plaintiffs in Clark were former shareholders of NCS who had attempted to use the action to obtain a class recovery on behalf of the shareholders of NCS "as it existed prior to its merger with Old Booth" Booth would not have been entitled to recovery from such an action; any recompense would have gone instead to the individual stockholders comprising the proposed class. The district court ruled, however, that there was no such entity as "NCS as it existed prior to its merger with Old Booth"; that although the plaintiffs were asserting direct claims and could recover individually, they could not recover on behalf of a class of shareholders of an entity that did not exist; and that the action was thus derivative in nature and any recovery therefrom, apart from the plaintiff' direct claims, was to inure to New Booth. See Clark I, 79 F.R.D. at 643-48; see also supra note 11.

25. $625 \mathrm{~F} .2 \mathrm{~d}$ at 51 . The events giving rise to the securities claims are murky at best. See Clark 1,79 F.R.D. at 643.

26. Clark II, 625 F.2d at 51. See infra note 37 and accompanying text. Jack Booth was the only member of the Booth board who was a defendant to the suit. Clark I, 79 F.R.D. at 650 .

27. The Fifh Circuit interpreted Booth's answer that any recovery from the suit should inure to it as "neutral." See Clark II,625 F.2d at 51. However, in view of the plaintiffs" attempts to recover on behalf of NCS as it existed prior to its merger with Booth, it is more accurate to state that Booth's answer was in opposition to any recovery that would not inure to it. See supra note 24.

28. The Booth board first unsuccessfully sought to deny the complaining shareholders leave to amend and later joimed with the newly named defendants in an unsuccessful attempt to dismiss the counts against them. Clark $I I, 625$ F.2d at 51 .

29. See Clark II, 625 F.2d at 51; Clark I, 679 F.R.D. at 645, 652; supra note 11.

30. See Clark I, 79 F.R.D. at 645. 
Apparently, Booth, Inc. and the defendants then continued without the plaintiffs and agreed to settle the derivative claims. ${ }^{32}$ Pursuant to Rule 23.1, the corporation presented the derivative settlement agreement to the district court for approval. ${ }^{33}$ The plaintiffs asserted that the district court should not approve the proposed compromise because the board of Booth, Inc., which ratified the settleinent, was not independent and was subject to conflicts of interest. ${ }^{34}$

The district court in Clark rejected the plaintiffs' contentions. The court found the directors of the Booth, Inc. to be independent ${ }^{35}$ because a majority of the board inembers had been appointed subsequent to the transactions giving rise to the suit, and because Jack Booth was the only board member who was a named defendant. ${ }^{36}$ The court rejected the argument that, by itself, the fact that Jack Booth and LNFC owned more than fifty percent of the stock of Booth, Inc. and could therefore elect and remove directors at will meant that the board could not be imdependent. ${ }^{37}$ Furthermore, the court found no evidence to support

31. See id. at 645,652 . In part, it was the plaintiff' refusal to participate in limited settlement negotiations that led the district court to conclude that "[t]he plaintiffs were not at all times acting in the best interests of the corporation." Id. at 656.

32. This summary of the settlement negotiations is drawn from both Clark $I$ and Clark $I I$. See Clark II, 625 F.2d at 51; Clark I, 79 F.R.D. at 645. Interestingly, the Fifth Circuit noted only that the settlement agreement proposed to the district court was negotiated without the presence or knowledge of the plaintiffs. See Clark II, 625 F.2d at 51. Apparently the Fifth Circuit was unaware that the district court had called for negotiations between all parties and that the plaintiffs had refused to settle the derivative claims alone.

33. Rule 23.1 also requires that notice of the setilement proposal be given to the stockholders of the aggrieved corporation. See supra note 5. After receiving such notice, no shareholders of Booth, Inc., other than the plaintiffs, objected to the proposed settlement. Clark I, 79 F.R.D. at 649.

Apparently as an extension of their attempts to recover on behalf of the shareholders of "NCS as it existed prior to its merger with Old Booth," see supra note 24, the plaintiffs also sought to have notice sent to the former shareholders of NCS. See Clark I, 79 F.R.D. at 646-49.

34. The plaintiffs also argued that the settlement proposal was not fair, adequate, and reasonable; that there was fraud and collnsion in the negotiations; and that notice of the settlement proposal should have been sent to the former shareholders of NCS. They also maintained that the law firm representing Booth, Inc. in the suit had a conflict of interest that required its disqualification. Clark I, 79 F.R.D. at 649. The district court rejected all of the plaintiffs' contentions. See id. at 646-53; Clark v. Lomas \& Nettleton Fin. Corp., 79 F.R.D. 658 (N.D. Tex. 1978) (separate opinion); see also infro notes $35-36$ and accompanying text.

35. Clark $I, 79$ F.R.D. at 650.

36. Id at 649. The district court required that a disinterested majority of the Booth, Inc. board approve the proposed compromise. See id. at 645. According to Booth, Inc. the seven member board that ratified the settlement consisted of five "outsiders" and only two "insiders." Defendant/Petitioner's Petition for Certiorari to the United States Supreme Court, at 7 n.8. Furthermore, Jack Booth was excluded from the meeting at which the Booth, Inc. board ratified the proposal. Clark I, 79 F.R.D. at 649.

37. Clark $I, 79$ F.R.D. at 649 . The Booth, Inc. charter forbade cumulative voting. Jack Booth owned approximately $45 \%$ of the then outstanding common stock; LNFC owned approximately 11\%. Thus, it was undisputed that each member of the board of Booth, Inc. held his 
the plaintiffs' claim that the settlement negotiations were collusive. ${ }^{38}$ After determining that the proposed compromise was fair, adequate, and reasonable, the court approved the settlement terms. ${ }^{39}$

On appeal, the Court of Appeals for the Fifth Circuit held that the district court's analysis of the independence of the Booth, Inc. board "simply does not address appellants' main poimt, which is that Jack Booth's and LNFC's combined shareholdings may have influenced the settlement terms." 40 The court stated that it must first decide whether or not the board of Booth, Inc. had authority to settle the corporation's legal claims.41 The court held that although a board of directors does possess such authority, it can only exercise that power if it is independent of the transactions giving rise to the suit. ${ }^{42}$ Though the district court found that the board of Booth, Inc. was independent, ${ }^{43}$ the court of appeals held that because Jack Booth and LNFC conld control the election of all members of the board, ${ }^{44}$ it could not be independent. ${ }^{45}$ Thus, it vacated the district court's approval of the proposed settlement.

The Court of Appeals for the Fifth Circuit in Clark rehed heavily on the reasoning of cases in which the demand requirement is excused. ${ }^{46}$ The court did not, however, consider any factors that might distimguish excuse-of-demand cases from settlement cases. It also ignored the relevant standard of appellate review: whether the trial court abused its discretion in approving or disapproving the proposed compromise. ${ }^{47}$ According to the court:

position by virtue of Jack Booth's and LNFC's combined vote. Clark $I I, 625$ F.2d at $52-53$ n.4. See infra notes $54,60,65-68$ and accoinpanying text.

38. "All of the evidence suggests to me that the settlement was rather the result of hard bargaining between the parties." Clark $I, 79$ F.R.D. at 652-53.

39. See id. at 648-52; infra notes $94-120$ and accompanying text.

40. Clark $I I, 625$ F.2d at 53 (einphasis added).

41. Id. at 52. It is interesting to note that the Fifth Circuit first characterized the derivative claims as belonging to the plaintiff/appellants, rather than to Booth, Inc.; the court corrected itself later in the same paragraph. Id. See supra note 11; infro note 104.

42. Clark $I I, 625$ F.2d at 52 .

43. See supra notes $35-36$ and accompanying text.

44. See supra note 37.

45. See infra notes $65-68$ and accoinpanying text.

46. See infra notes 54-80 and accoinpanying text.

47. "Great weight is accorded [the trial court judge's] views because he is exposed to the litigants, and their strategies, positions and proofs. He is aware of the expense and possible legal bars to success. Simply stated, he is on the firing line and can evaluate the action accordingly." Ace Heating \& Plumbing Co. v. Crane Co., 453 F.2d 30, 34 (3d Cir. 1971). In Young v. Katz, 447 F.2d 431 (5th Cir. 1971), a case cited in Clark II, the Fifth Circuit quoted approvingly from Neuwirth v. Allen, 338 F.2d 2 (2d Cir. 1964), in which the Second Circuit stated that in approving or rejecting a settlement proposal, "[i]he action of the District Court is presumptively right, and will not be set aside unless clearly shown to have been wrong." 447 F.2d at 432-33. Accord Grunin v. International House of Pancakes, 513 F.2d 114, 123 (8th Cir. 1975); Flinn v. FMC 
The board's conflict of interest could not be cured by judicial approval of the settlement terms. "Fairness," "reasonableness," and "adequacy" in this context connote only that the terms fall within a range of magnitude that the directors, in the exercise of their business judgnient, could legitimately accept. This 'range of reasonableness' . . plainly may encompass terms that, while apparently 'fair,' may nonetheless have suffered from incestuous negotiation. It is indeed for this very reason that we bifurcate our review of derivative settlements . . . by focusing on conflicting interests independently of the terms themselves. Our holding pretermits review of whether the terms actually negotiated were "reasonable" in relation to the claims surrendered. That question will arise, if ever, only when this case is settled by parties unbeholden to the alleged wrongdoers. ${ }^{48}$

The Clark holding requires a court to reject a settlement proposal when it finds a mere possibility of fraud or collusion in the settlement negotiations. ${ }^{49}$ This possibility is automatically established when a board of directors is not independent. ${ }^{50}$ Because any group of stockholders controlling a majority of the shares can control the entire board in most states, Clark will allow a derivative plaintiff effectively to prevent a corporation from settling its claims by merely naming the controlling shareholders as defendants. ${ }^{51}$ Thus, the Clark doctrine will greatly reduce the number of in-court settlements. ${ }^{52}$ If the Clark court's holding actually does protect aggrieved corporations more than the traditional settlement analysis, it could be argued that this benefit outweighs the costs inherent in discouraging in-court settlements. ${ }^{53}$

Corp., 528 F.2d 1169, 1173 (4th Cir. 1975), cert. denied, 424 U.S. 967 (1976); City of Detroit v. Grinnell Corp., 495 F.2d 448, 454-55 (2d Cir. 1974); Umited Founders Life Ins. Co. v. Consumers Nat'1 Life Ins. Co., 447 F.2d 647, 655 (7th Cir. 1971).

48. Clark $I I, 625$ F.2d at 54. The Clark $I I$ court did not fully explain what it meant by its holding. It noted that when the board is independent of the transactions giving rise to the derivative suit, it is empowered to negotiate and approve settlement terms that will bind the corporation, subject to judicial approval of the settlement proposal. However, when a board is non-imdependent, under the Clark $I I$ court's analysis it lacks the power to bind the corporation, so that no matter what compromise this board may negotiate and ratify, it cannot effectuate an im-court settlement and the attendant surrender of the corporation's legal claims. See generally Haudek, The Settlement and Approval of Stockholders'Actions-Part II: The Settlement, 23 Sw. LJ. 765, 770, 799 (1969).

49. See supra notes $41-45,48$ and accompanying text; imfra notes $140-42$ and accompanying text.

50. See Clark II, 625 F.2d at 53-54.

51. See supra note 13 .

52. See infra notes $141-42$ and accompanying text.

53. The principle that public policy favors the settlement rather than litigation of legal claims is well established. See, eg., Williams v. First Nat'I Bank, 216 U.S. 582, 595 (1910); Newman v. Stein, 464 F.2d 689, 692 n.7 (2d Cir.), cert. denied, 409 U.S. 1039 (1972); Norman v. McKee, 290 F. Supp. 29, 32 (N.D. Cal. 1968), affd, 431 F.2d 769 (9th Cir. 1970), cert. denied, 401 U.S. 912 (1971); see also Haudek, supra note 48 , at 793. 
However, if this holding does not provide benefits to offset the reduction in derivative settlements, it should be overturned.

\section{The Demand Requirement and the Derivative SetTlement Process}

\section{A. The Demand Requirement.}

In vesting power to inanage the corporation in a board of directors, the legislature necessarily assumes that the board ineinbers will use their independent business judgment to further the interests of the corporation and not to further their own personal interests. ${ }^{54}$ As long. as board ineinbers exercise "disinterested" judgment in directing the corporation's affairs, courts defer to their decisions and will not interfere with their actions. ${ }^{s 5}$

In deference to the statutory authority vested in the board of directors to inanage the corporation, Rule 23.1 requires that a stockholder demand that the board act to vindicate an alleged corporate cause of action before the stockholder pursues it on a derivative basis. ${ }^{56}$ The demand informs the board of the corporation's alleged claim and gives the board the opportumity to control the hitigation as it controls the corporation's other affairs. ${ }^{57}$ Rule 23.1 thus requires a complaining stockholder to exhaust intracorporate remedies before invoking the extraordinary judicial interference with the corporate structure that

54. See, eg., Clark $1 I, 625$ F.2d at 52 (citing Galef v. Alexander, 615 F.2d 51, 58.61 (2d Cir. 1980)); Maldonado v. Flynn, 413 A.2d 1251, 1263 (Del. Ch. 1980); Note, Business Judgment Rule, supra note 13, at 601 .

55. In Auerbach v. Benneth, 47 N.Y.2d 619, 630-31, 393 N.E.2d 994, 1000, 419 N.Y.S.2d 920, 926-27 (1979), the court stated:

[C]ourts are ill equipped and infrequently called on to evaluate what are and must be essentially business judgments. The authority and responsibilities vested in corporate directors both by statute and decisional law proceed on the assumplion that inescapably there can be no available objective standard by which the correctness of every corporate decision inay be measured, by the courts or otherwise. Even if that were not the case, by definition the responsibility for business judgments inust rest with the corporate directors; their individnal capabilities and experience peculiarly qualify thein for the discharge of that responsibility. Thus, absent evidence of bad faith or fraud . . . the courts must and properly should respect their determinations.

See also Corbus v. Alaska Treadwell Gold Mining Co., 187 U.S. 455, 463 (1903); Note, Demand and Standing Requirements, supra note 12, at 171. Such business judgments include the determination of whether or not a corporation should pursue its legal claims. See In re Penn Central Sec. Litig., 367 F. Supp. 1158, 1163 (E.D. Pa. 1973); Note, Special Litigation Committees \& The Business Judgment Rule, 14 ConN. L. Rev. 193, 195-96 (1981). See supra note 16; infra notes 60-62 and accompanying text.

56. See supra note 12. For the text of Rule 23.1, see supra note 5.

57. See Note, Demand and Standing Requirements, supra note 12, at 171-72; see also, United Copper Sec. Co. v. Amalgamated Copper Co., 244 U.S. 261, 263 (1917); Corbus v. Alaska Treadwell Gold Mining Co., 187 U.S. 455, 462 (1903). 
necessarily occurs when a stockholder maintains an action derivatively against the wishes of the board. 58

When the stockholder inakes the required demand, the board may assume control of the suit; it may take no action and allow the complaining stockholder to proceed derivatively or it nay reject the deinand, depriving the stockholder of the power to inaintain the suit. 59 If the board is independent of the transactions that give rise to the suit, courts will review its decision under the deferential standard of the business judgment rule. ${ }^{60}$ Thus, before a corporation is embroiled in litigation that may.impair its ability to function, ${ }^{61}$ the board can terminate "strike suits" 62 and other suits that do not serve the interests of the corporation.

In some cases, however, the corporation's claim will be against members of the board of directors. ${ }^{63}$ In such cases, even when it is in the corporation's true imterest to sue some or all of its directors or members, it is unlikely that board meinbers will make an unbiased judgment about the merits of sumg theinselves or their co-directors on the corporation's behalf. ${ }^{64}$ Recognizing the realities of corporate management and the limitations of the statutory assumption that board members will act with personal disimterest for the independent benefit of their corporation and its stockholders, ${ }^{65}$ courts excuse the demand re-

58. The necessity for judicial intervention arises when a demand is required but not made, or when a demand is made and rejected by the board. See United Copper Sec. Co. v. Amalgamated Cópper Co., 244 U.S. 261, 263-64 (1917), quoted in note 16 supra; Hawes v. Oakland, 104 U.S. 450, "460-61 (1881); Heit v. Baird, 567 F.2d 1157, 1160 (1st Cir. 1977); Leff v. CIP Corp., 540 F. Supp. 857, 868 (S.D. Ohio 1982); Colan v. Monumental Corp., 524 F. Supp. 1023, 1027 (N.D. 11l. 1981); infro note 68 .

59. See Note, Demand and Standing Requirements, supro note 12, at 171-72; infro notes 65-68 and accoinpanying text.

60. See generally Burks v. Lasker, 441 U.S. 471, 478, 480, 485 (1979); United Copper Sec. Co. v. Amalgamated Copper Co., 244 U.S. 261, 263-64 (1917); Galef v. Alexander, 615 F.2d 51, $57-62$ (2d Cir. 1980); Polin v. Conductron Corp., 552 F.2d 797, 809 (8th Cir.), cert. denied, 434 U.S. 857 (1977); Note, Business Judgment Rule, supro note 13, at 600-01.

61. See Cox, Searching for the Corporation's Voice in Derivative Suit Litigation: A Critique of Zapata and the ALI Project, 1982 DUKE L.J. 959, 960; Note, Special Litigation Committees \& The Business Judgment Rule, 14 CONN. L. REv. 196 n.15, 200.

62. A "strike suit" is a frivolous derivative claim brought by a shareholder for the purpose of enticing the corporation to pay the shareholder and/or his attorney to drop the suit. For a discussion of the classic strike suit, see Note, Extortionate Corporate Litigation: The Strike Suti, 34 Colum. L. Rev. 1308 (1934). See infra notes 82-85, and accompanying text.

63. See supra note 11.

64. See, e.g., Galef v. Alexander, 615 F.2d 51, 59 (2d Cir. 1980) (citing Cathedral Estates, Inc. v. Taft Realty Corp., 228 F.2d 85 (2d Cir. 1955)); Cohen v. Industrial Fin. Corp., 44 F. Supp. 491 , 494 (S.D.N.Y. 1942), quoted in Clark II, 625 F.2d at 53. The obvious bias of the board in such cases encourages courts to be lenient in excusing the demand requirement. See, e.g. , deHaas v. Empire Petroleum Co., 435 F.2d 1223, 1228 (10th Cir. 1970); Note, Demand and Standing Require. ments, supro note 12 , at 170 .

65. See supra note 54 and accompanying text. 
quirement where a complaining stockholder alleges, with particularity, ${ }^{66}$ facts demonstrating that the board would not seriously consider pursuit of the claims against its members. ${ }^{67}$ In such cases, courts will allow the complaining shareholder to maintain the action derivatively, without first requiring the shareholder to make a demand. ${ }^{68}$

The board may regain its power to control its legal claims, however, by establishing anew its imdependence. ${ }^{69} \mathrm{~A}$ board can recapture

66. See, eg., Leff v. CIP Corp., 540 F. Supp. 857, 868 (S.D. Ohio 1982); see also FED. R. CIV. P. 23.1, quoted in supra note 5.

67. See supra text accompanying notes 54-55, 63-64. Courts have not provided a consistent definition of what constitutes sufficient "futility" to excuse the demand requirement. " "P]robably. the most straightforward approach is to admit frankly that it lies with the sound discretion of the court to determine the necessity for a demand.' 3B J. MOORE, MOORE's FEDERAL PrACTICE, 23.1.19 at 254 (2d ed. 1974)." Abbe v. Goss, 411 F. Supp. 923, 924 (S.D.N.Y. 1975). See Note, Demand and Standing Requirements, supra note 12, at 173-82; Note, Business Judgment Rule, supra note 13, at 605-07.

The majority view, however, is that the mere naming of members of a board as defendants is an insufficient reason to excuse the demand. "To allow one shareholder to incapacitate an entire board of directors merely by leveling charges against them gives too much leverage to dissident shareholders." Lewis v. Anderson, 615 F.2d 778, 783 (9th Cir. 1979), cert. denied, 449 U.S. 869 (1980); see also In re Kaüfiman Mut. Fund Actions, 414 U.S. 857 (1973); Clark I, 79 F.R.D. at 649; cf. Note, Demand and Standing Requirements, supra note 12, at 173-74. The Clark court, however, stated that " $[w]$ here as here, the controlling shareholders are named defendants, demand 'futility' is presumed . . . W We need not now decide whether, given the dynamies of Mr. Booth's and LNFC's respective shareholdings and litigation interests, Booth's directors lawfully could compromise those counts in which Mr. Booth is not named." Clark II, 625 F.2d at 53, $54 \mathrm{n} .6$ (emphasis added). But see Galef v. Alexander, 615 F.2d 51, 59 (2d Cir. 1980) ("It the rationale of the cases holding that demand must be made even if the directors have been or may be made defendants, is not that the directors can preclude suit despite being defendants, but rather that they might cause the corporation to pursue the suit despite being defendants"). at 172 .

68. See Clark II, 625 F.2d at 53-54; Note, Demand and Standing Requirements, supra note 12,

When a stockholder does make a demand on the board of directors, the board may reject the demand. However, such a decision by a non-independent board will not receive the protection of the business judgment rule. As is the case when the demand is excused, the facts necessary to support a finding that a board is incompetent to reject the demand are dependent upon the degree of control exercised on the board by the alleged wrongdoers. However, some courts have required, a lesser showing of non-imdependence in order to strip the board of the power to reject the demand than is required to excuse the demand; one court has rejected this distinction. Compare Clark II, 625 F.2d at 54 n.5 (citing Galef v. Alexander, 615 F.2d 51, 59 (2d Cir. 1980)), and Heit v. Baird, 567 F.2d 1157, 1162 n.6 (1st Cir. 1977) with Lewis v. Curtis, 671 F.2d 779, 785-86 (3d Cir.), cert. denied, 103 S. Ct. 176 (1982). See Note, Business Judgment Rule, supra note 13, at 606-08; Note, Demand and Standing Requirements, supra note 12, at 193-98.

69. “At first blush, it would seem anomalous that corporate directors could tardily and peremptorily intervene to extinguish shareholder derivative actions, over the plaintiffs' heads and despite their objections. But while the propriety of such intervention may be questioned, the power can not be." Clark II, 625 F.2d at 52; see also Joy v. North, 519 F. Supp. 1312, 1320 (D. Conn. 1981), rev'd on other grounds, 692 F.2d 880 (2d Cir. 1982); Winkleman v. General Motors Corp., 48 F. Supp. 504, 514 (S.D.N.Y. 1942); infra notes $84-85$ and accompanying text; supra notes 54-55 and accompanying text. 
its independent status through a change in its composition; ${ }^{70}$ however, in recent years the most common means has been through the creation of a special litigation committee (SLC). An SLC is a subcommittee of the board, comprised of members untainted by the shareholder's claims, and vested by the board with its statutory power to control the derivative suit. ${ }^{71}$ The SLC is now widely used in derivative litigation and has repeatedly received judicial approval. ${ }^{72}$

The SLC conducts an investigation into the merits of the derivative suit and reports to the board with its recommendations. ${ }^{73}$ When an SLC's recommendations are challenged in court, in all jurisdictions except Delaware, if a court finds that the SLC is independent and that it conducted a good faith and thorough investigation, the court will review the committee's recommendations under the deferential standard of the business judgment rule. ${ }^{74}$ This deferential review of SLC recommendations has been criticized because SLCs invariably recommend termination of derivative suits. ${ }^{75}$

70. See Brody v. Chemical Bank, 482 F.2d 1111, 1114 (2d Cir.), cert. denied, 414 U.S. 1104 (1973); Nelsou v. Pacific Southwest Airlines, 399 F. Supp. 1025, 1030 (N.D. Cal. 1975); Independent Investor Protective League v. Saunders, 64 F.R.D. 564, 571 (E.D. Pa. 1974).

71. See generally Cox, supra note 61, at 959; Steinberg, The Use of Special Litigation Committees To Terminate Shareholder Derivative Suits, 35 U. MiamI L. REv. 1 (1980); Note, Special Litigation Committees \& the Business Judgment Rule, 14 ConN. L. REv. 193 (1981); Note, Business Judgment Rule supra note 13, at 600 .

72. See, e.g., Burks v. Lasker, 441 U.S. 471 (1979); Lewis v. Anderson, 615 F.2d 778 (9th Cir. 1979), cert. denied, 449 U.S. 869 (1980); Abbey v. Control Data Corp., 603 F.2d 724 (8th Cir. 1979), cert. denied, 444 U.S. 1017 (1980); Cramer v. General Tel. \& Elec. Corp., 582 F.2d 259 (3d Cir. 1978), cert. denied, 439 U.S. 1129 (1979); Grossman v. Johnson, 89 F.R.D. 656 (D. Mass. 1981), affd, 674 F.2d 115 (1st Cir.), cert. denied, 103 S.Ct. 85 (1982); Watts v. Des Moines Register and Tribune, 525 F. Supp. 1311 (S.D. Iowa 1981); Zapata Corp. v. Maldonado, 430 A.2d 779, 78889 (Del. 1981). The SLC offers a great deal of protection to the corporation; however, because a biased board has the opportunity to carefully choose the inembers of the SLC, the committee is likely to have a "structural bias" against derivative suits and great sympathy for the board. See Cox, supra note 61, at 962; Note, Business Judgment Rule, supra note 13, at 619-22.

73. See, e.g., Cox, supra note 61, at 961-62 n.9; Steinberg, supra note 71, at 2.

74. See, e.g., Lewis v. Anderson, 615 F.2d 778, 783-84 (9th Cir. 1979), cert. denied, 449 U.S. 489 (1980); Abbey v. Control Data Corp., 603 F.2d 724, 727-30 (8th Cir. 1979), cert. denied, 444 U.S. 1017 (1980); Auerbach v. Bemuett, 47 N.Y.2d 619, 393 N.E.2d 994, 419 N.Y.S.2d 920 (1979).

If the court does not find that the SLC is independent, it will not respect the committee's recommendations. Courts will generally ignore the more subtle form of bias that is part of the committee members' general attitude as corporate directors, see infra text accompanying note 75 . The willingness of courts to disregard an SLC"s "structural bias" has been cogently criticized. See Cox, supra note 61, at 962-63, 1007-11; Note, Business Judgment Rule, supra note 13, at 600-03, 601 n.14, 616-33. Nevertheless, except for the Zapasa case in Delaware, see infra notes 76-80 and accompanying text, and possibly Clark II, see supra note 67 and accompanying text, there has been no indication of a heightened judicial concern about the effects of structural bias on the decisions of SLCs. But of. Joy v. North, 692 F.2d 880 (2d Cir. 1982).

75. See Cox, supra note 61 , at $962-63$. 
In Zapata Corp. v. Maldonado, ${ }^{76}$ the Delaware Supreme Court at least partially responded to such criticism by establishing a more rigorous standard for review of SLC recommendations. In addition to a court's review of the independence of an SLC and the thoroughness of its good faith investigation, the court may also apply "its own independent business judgment" to determine whether the SLC's recommendations "would simply prematurely terminate a stockholder grievance deserving of further consideration in the corporation's interest."77 In explaining this deviation from the normal application of the busmess judgment rule to the decisions of SLCs, ${ }^{78}$ the Zapata court stated: "We recognize the danger of judicial overreaching but the alternatives seein to us to be outweighed by the fresh view of a judicial outsider."79 Thus, in Delaware, the decisions of independent SLCs will not necessarily receive the same judicial deference accorded the decisions of an independent board of directors. ${ }^{80}$

\section{B. The Derivative Settlement Process.}

1. The Court's Role. Rule 23.1 requires court approval of derivative suit settlements primarily because the motives of all parties to such a settlement are suspect. ${ }^{81}$ Many factors may prompt a party to accept an inadequate settlement without regard for the true interests of the corporation on behalf of which the suit is brought. Members of the board may support an inadequate settlement to shield themselves from substantial personal liability or to avoid the revelation during additional discovery or at trial of potentially einbarassing facts about board actions. The plaintiff may also accept a settlement for personal rewards. He may have imitiated the derivative suit only because he thought that the defendants would pay him to drop it.82 The plaintiff's counsel may settle the suit if the settlement will bring him attorney's fees proportionately larger than those he might receive after a success-

76. 430 A.2d 779 (Del. 1981).

77. Id. at 789. The precise meaning and consequent aspect of the Zapata holding is unclear. The Zapasa court clearly sought to establish a more rigorous standard of review of SLC recommendations. However, this seemingly heightened standard is intertwined with language both reminiscent of the deferential business judgment rule and ambiguous with regard to the nature of the overriding public policy concern that will allow a Delaware court to disregard a reasonable and well-supported SLC recommendation to terminate a suit. See Cox, supra note 61, at 976-94.

78. See supre note 74 and accompanying text.

79. $430 \mathrm{~A} .2 \mathrm{~d}$ at 788.

80. See id. at 787; supre notes $59-60$ and accompanying text.

81. See McLaughlin, Capacity of Plaintif-Stockholder to Terminate a Stockholder's Suit, 46 YALE L.J. 421, 435 (1936); see also Birnbaum v. Birrell, 17 F.R.D. 409, 411 (S.D.N.Y. 1955).

82. See supra note 62. 
ful adjudication of the derivative claims. ${ }^{83}$ Although the derivative plaintiff is the party that initiates the suit, ${ }^{84}$ courts routinely approve derivative settlements over the plaintiff's vehement objections. ${ }^{85}$

Thus, when reviewing a settlement proposal, courts act as guardians of the corporation's interest and as third parties to the settlement agreement. ${ }^{86}$ A court's presence cannot always thwart parties determined to defraud the corporation:87 however, by acting as if it were an "independent board of directors" 88 in judging the inerits of a proposed settlement, a court can provide substantial protection against such action. ${ }^{89}$ In fulfilling its role as independent arbiter of the fairness of the settlement, the court must closely analyze the case at hand.90 By the time the parties present a derivative settlement proposal to the court for review, the court will usually be familiar with the litigation and the

83. See, e.g., Saylor v. Lindsley, 456 F.2d 896, 900-01 (2d Cir. 1972); see also Prandini v. National Tea Co., 557 F.2d 1015, 1021 (3d Cir. 1977); Woinen's Comm. for Equal Employment Opportunity v. National Broadcasting Co., 76 F.R.D. 173, 180 (S.D.N.Y. 1977); cf. Haudek, supra note 48 , at 768 .

84. See Haudek, supra note 48 , at $767-70$.

85. For cases concerning the acceptability to a court of a proposed settlement to which the derivative suit plaintiff objects, see Clark II, 625 F.2d at 51; Flinn v. FMC Corp., 528 F.2d 1169, 1173 (4th Cir. 1975), cert. denied, 424 U.S. 967 (1976); Saylor v. Lindsley, 456 F.2d 896, 897, 899 900 (2d Cir. 1972); Denicke v. Anglo Cal. Nat'l Bank, 141 F.2d 285, 287 (9th Cir.), cert. denied, 323 U.S. 739 (1944); Ellis v. Naval Air Rework Facility, 87 F.R.D. 15, 18 (N.D. Cal. 1980), aff'd, 661 F.2d 939 (9th Cir. 1981).

86. See, eg., Masterson v. Pergament, 203 F.2d 315, 330 (6th Cir.), cert. denied, 346 U.S. 832 (1953); Denicke v. Anglo Cal. Nat'l Bank, 141 F.2d 285, 288 (9th Cir.), cert. denied, 323 U.S. 739 (1944); Boggess v. Hogan, 410 F. Supp. 433, 437 (N.D. Ill. 1975); Zerkle v. Cleveland-Cliffs Iron Co., 52 F.R.D. 151, 159 (S.D.N.Y. 1971); Norman v. McKee, 290 F. Supp. 29,32 (N.D. Cal. 1968), affd, 431 F.2d 769 (9th Cir. 1970).

87. For instance, in Alleghany Corp. v. Kirby, 218 F. Supp. 164 (S.D.N.Y. 1963), the plaintiff collaterally attacked a settlement agreement approved by a state court, requesting that the settlement be set aside because of the alleged conduct of certain parties, conduct of which the state court had been unaware. See id. at 175-76. But of. Masterson v. Pergament, 203 F.2d 315, 330 (6th Cir.), cert. denied, 346 U.S. 832 (1953) (implying that the mere presence of the court as a third party to the compromise precludes fraud or collusion). Haudek, supra note 48 , at 771 , calls Masterson an "extreme" view: it fails to take into account the ingenuity of hitigants in overburdened courts.

88. Haudek, supra note 48 , at 792 .

89. See infra notes $116-20$ and accompanying text.

90. In the derivative settlement process, a court has neither a duty nor a right to make conclusions of law or fact regarding the merits of the corporation's claims. See, eg., City of Detroit v. Grinnell Corp., 495 F.2d 448, $462-63$ (2d Cir. 1974). However, the court inust be sufficiently informed of the facts and law of the case to make and articulate an intelligent judgment about the merits of the settlement proposal. Unless the "[c]ourt has available to it either hard facts or a rational explanation for its inability to discover them, it does not know the range of appropriate settlement and it is flying blind." Weiss v. Chalker, 55 F.R.D. 168, 169 (S.D.N.Y. 1972). See Pettway v. American Cast Iron Pipe Co., 576 F.2d 1157, 1169 (5th Cir. 1978); City of Detroit v. Grinnell Corp., 495 F.2d 448, 456, 461 (2d Cir. 1974); West Virginia v. Chas. Pfizer \& Co., 440 F.2d 1079, 1085-86 (2d Cir.), cert. denied, 404 U.S. 871 (1971). 
parties.91 Furthermore, opponents of the proposed compromise must be allowed to develop and enter into the record facts supporting their objections. ${ }^{92}$ After hearing the evidence, the court will determine whether to accept the settlement proposal; if it rejects the proposal, it can often guide the parties to more equitable settlement terms. ${ }^{93}$

2. The Court's Analysis. In view of the potential for illicit conduct in the derivative settlement process, ${ }^{94}$ the traditional analysis of settlement proposals requires the reviewing court first to. determine whether the settlement negotiations were conducted in "good faith" and were free from "fraud or collusion."95 Although a court reviewing a settlement proposal should, logically, be more interested in the results achieved rather than in the conduct of the negotiations, ${ }^{96}$ courts seem willing to reject a proposed settlement tainted by fraud "no matter how acceptable it may otherwise appear." 97 However, few cases explain what conduct is sufficiently fraudulent or collusive to compel a court to reject a settlement proposal without also considering its fairness, adequacy and reasonableness. ${ }^{98}$

The Court of Appeals for the Fifth Circuit in Clark apparently intended to follow the traditional analysis of whether a proposed settlement is tainted by fraud or collusion. ${ }^{99}$ The circuit court did not, however, find that the obvious potential for the board's conflict of interest ${ }^{100}$ had in fact materialized into fraud or collusion in the negotiations; 101 indeed, the district court had found that the plaimtiffs failed to show actual fraud or collusion in the negotiations. ${ }^{102}$ Rather, guided

91. In Clark $I$, the district court repeatedly emphasized its familiarity with the litigation, the record of which filled approximately thirty thousand pages. See 79 F.R.D. at 643-44, 650, 652.

92. For instance, in Girsh v. Jepson, 521 F.2d 153, $157-58$ (3d Cir. 1975), and in Cohen v. Young, 127 F.2d 721, 725-26 (6th Cir. 1942), the appellate courts reversed the lower courts' approvals of settlement proposals because the lower courts failed to allow objectors to state their cases.

93. See Seigal v. Merrick, 590 F.2d 35, 39 (2d Cir. 1978); see also In re General Motors Corp. Engine Interchange Litig., 594 F.2d 1106, 1126 n.30 (7th Cir.), cert. denied, 444 U.S. 870 (1979).

94. See supra notes 81-83 and accompanying text.

95. See, eg., Flinn v. FMC Corp., 528 F.2d 1169, 1173 (4th Cir. 1975), cert. denied, 424 U.S. 967 (1976); Young v. Katz, 447 F.2d 431, 433 (5th Cir. 1971); In re Montgomery County Real Estate Antitrust Litig., 83 F.R.D. 305, 315 (D. Md. 1979); Percodani v. Riker-Maxson Corp., 50 F.R.D. 473, 477 (S.D.N.Y. 1970).

96. See Haudek, supra note 48 , at 771 .

97. Id. at 772 .

98. Haudek cites three examples of fraudulent and collusive conduct: a bribe promised to the plaintiff's representative; a stockholder's derivative action "planted" by the defendants; and an excessive fee for plaintiff's counsel in return for an inadequate settlement. Id.

99. Clark II, 625 F.2d at 54.

100. See supra note 37; supra text accompanying note 44 .

101. See supra text accoinpanying note 40.

102. See supra notes $35-38$ and accompanying text. 
by the reasoning of cases excusing the demand requirement, the Court of Appeals for the Fifth Circuit held that the mere possibility of fraud or collusion as evidenced by a board's non-independence compelled the court, as a matter of law, to reject the proposed compromise without considering the fairness, adequacy and reasonableness of the settlement terms. ${ }^{103}$

The Clark analysis is unprecedented. ${ }^{104}$ The few relevant reported cases indicate that only textbook cases of fraud or collusion have prompted courts to reject a settlement proposal without otherwise considering the fairness, adequacy and reasonableness of the proposed

103. See supra notes $40,48-50$ and accompanying text. Thus, the Fifth Circuit never focused on the actual conduct of the negotiations. Rather, the court was preoccupied with its suspicions about what the negotiations might have been like.

104. The Clark court's deviation from the traditional standards of the derivative settlement process is best illustrated by two cases in which courts were confronted with settlement proposals negotiated by non-independent boards. In Winkelman v. General Motors Corp., 48 F. Supp. 490 , 495 (S.D.N.Y. 1942), a settlement was negotiated after a favorable decision for the plaintiffs, but before judgment had been entered. The Winkelman court stated:

It would seem that where the corporation's affairs are under the control of a board of directors, the adequacy of the settlement of a judgment obtained in a stockholder's action would be for the board to decide, if the board is disinterested and not involved in the litigation.... . But in the present case there would be a serious obstacle to such a course, once judgment is entered, because most of the present board of directors of General Motors Corporation are defendants herein and they control large blocks of stock, although not a majority of the stock. U.S. Limes Inc. et al. v. U.S. Lines Co. et al., 2 Cir., 96 F.2d 148, 152. However, even in such a situation, I do not beheve that Rule 23(c) [predecessor to Rule 23.I] would bar this court, if it were asked to do so, from itself inquiring into the matter and expressing views as to the adequacy of a proposed settlement of a judgment, after notice to all stockholders. That would be an aid to the administration of justice; it would assist in properly ending the litigation; and the Court's sanction of the settlement would make less likely the institution of further stockholder's actions based on the alleged inadequacy of the settlement itself.

Id. at 495 . The case cited by the Winkelman court, United States Lines, Inc. v. United States Lines Co., 96 F.2d 148 (2d Cir. 1938), also addressed the question whether an interested board could settle a derivative suit. In United States Lines, the court rejected the settleinent, reasoning:

[We are not] satisfied that the value of the consideration offered for the discontinuance [of the derivative suit] is sufficient to justify the [approval of the settlement proposal] .... We do not say that the stock owned by the defendants could not be voted in favor of the settlement, but hold that the settlement effected by a majority consisting mainly of the defendants who were in control of the corporation should not be sanctioned without clear proof that it was advantageous to the corporation and its stockholders. We are not satisfied that such proof has been furnished by the defendants.

Id. at 152. Thus, in neither Winkelman nor United States Lines were the board members "independent" of the transaction giving rise to the derivative suits; in fact, in Winkelman the defendants had already been found liable. The courts did not question the propriety of the board of directors' exercise of their power to negotiate and bind their corporation to a settlement; in each case, the court reached its decision by examining the faimess, adequacy, and reasonableness of the proposal.

Two Fifth Circuit decisions cited by the court in Clark $I I$, Miller v. Republic Nat'I Life Ins. Co., 559 F.2d 426, 428-29 (5th Cir. 1977), and Young v. Katz, 447 F.2d 431, $432-33$ (5th Cir. 1971), do not support the Clark court's holding that a non-independent board may not settle a derivative suit. Rather, the two cases stand for the simple proposition that a court must search for fraud and collusion in settlement negotiations. Neither case specifies the precise nature of that search. 
terms. ${ }^{105}$ The well-settled legal principle that a court must not become a party to illegitimate conduct through judicial enforcement of illegal agreements justifies a court's searching inquiry into an allegedly fraudulent or collusive settlement. ${ }^{106}$ If there is sufficient direct or circumstantial evidence of such misconduct, the court must disapprove the proposed compromise.

105. See supra notes $97-98$ and accompanying text. Courts will expend considerable effort to ensure that a settlement proposal is not tainted by fraud or collusion. See, e.g., Alleghany Corp. v. Kirby, 218 F. Supp. 164 (S.D.N.Y. 1963) (conducting im-depth review of circumstantial evidence to determine if agreement is possibly fraudulent or collusive). Nevertheless, courts must often approve settlements in questionable circumstances. In In re General Motors Corp. Engine Interchange Litig., 594 F.2d 1106 (7th Cir.), cert. denied, 444 U.S. 870 (1979), a plaintiff asserted that it was inadequately represented in settlement negotiations. The court indicated, in dicta, that even if the plaintiff were wrongly excluded and the settlement negotiations were therefore "improper," the district court could have approved the proposed settlement if the proponents of the settlement had been able to "bear the heavier burden of establishing fairuess by clear and convincing evidence." Id at 1126 n.30.

In American Employers' Ins. Co. v. King Resources Co., 20 Fed. R. Serv. 2d 161 (Callaghan) (D. Colo. 1975), a defendant/intervenor in a class action asserted that it had been inadequately represented in settlement negotiations and thus could not be bound by the settlement agreement. The court held that "as to the relative benefits which the various individuals and groups within the defendant class are to receive from the settlement, there are obvious conflicts . . . . [T] hese conflicts and any disparity in benefits go to the 'fairness' of the settlement . . . . [citation omitted] [T] he possibility of unfairuess or collusion does not mean, as a matter of law, that the court may not consider the settlement plan . ..."Id at 165 (emphasis in original).

Thus, in both General Motors and King Resources, the settlement negotiations were not as "proper" as they would have been if all the parties had participated therem. However, because there was no showing of actual fraud or collusion, the courts evaluated the settlement proposals solely on the basis of the fairness, adequacy, and reasonableness of the proposed terms.

106. This principle originates from the law of contracts, where "[t]he policy of the law is clear--if the contract is for an illegal purpose, the court inay not lend its aid to enforce it, but must leave the parties where it finds them." Bauman \& Vogel, C.P.A. v. Del Vecchio, 423 F. Supp. 1041, 1044 (E.D. Pa. 1976). "This is done, not to punish one party [to an illicit contract] more severely than another, but to maintain the dignity of the court and for reasons of general public policy." Manning v. Metal Stamping Corp., 396 F. Supp. 1376, 1379 (N.D. IIl. 1975), affd, 530 F.2d 980 (7th Cir. 1976). See United States v. Farrell, 606 F.2d 1341, 1348-49 (D.C. Cir. 1979); Kaiser-Frazer Corp. v. Otis \& Co., 195 F.2d 838, 843-44 (2d Cir. 1952); see also Levy v. Kansas City, Kan., 168 F. 524, 525-26 (8th Cir. 1909); Brooms Legal Maxims 125-27, 690-93 (6th ed. 1868).

The analogy from the law of contracts to the derivative settlement process is clear and inviting. The primary purpose of the Rule 23.1 requirement of judicial approval of settlement proposals is to protect against fraudulent or collusive settlement agreements. See, e.g., Birnbaum v. Birrell, 17 F.R.D. 409, 411 (S.D.N.Y. 1955); see supra notes 81-83 and accompanying text. Thus, if a derivative settlement proposal is tainted by fraud or collusion, a court must not lend the judicial hand that is necessary to effectuate the settlement of the corporation's claims. While it seems logical to assume that any fraud or collusion perpetrated in settlement negotiations would result in a reduced recovery for the corporation, questions regarding the merits of the terms of a fraudulent-or collusive settlement proposal are in fact irrelevant. For in view of the overriding needs to protect the integrity of the judiciary and the public policy behind Rule 23.1 , even if the proposed settlement could be found to be fair, adequate and reasonable, a court would have to reject it if the negotiations leading thereto were tainted by fraud or collusion. 
This rationale does not, however, explain the Clark court's refusal to affirm the trial court's approval of a settlement proposal simply because there was the potential for fraud and collusion. In Clark, the plaintiff failed to prove that the potential conflicts of interest had in fact materialized into fraud or collusion; ${ }^{107}$ thus, under the standard test, ${ }^{108}$ the Clark court should have affirmed the trial court's findings that the settlement was free of fraud and was fair, adequate, and reasonable.

In reviewing a settlement proposal under the fair, adequate, and reasonable standard, 109 the court's most important task is to balance the strength of the corporation's claims agaimst the terms of the proposed compromise. ${ }^{110}$ The court must first evaluate the likelihood that the corporation would prevail at trial'il by weighing the risks and burdens of establishing both liability and damages in light of the uncertamties of law and the facts of the case. ${ }^{112}$ If the corporation's claims

107. See supra notes 100-02 and accompanying text.

108. See supra note 47 and accompanying text.

109. See, eg., Miller v. Republic Nat'l Life Ins. Co., 559 F.2d 426 (5th Cir. 1977); Clark 1, 79 F.R.D. at 648; Schimmel v. Goldman, 57 F.R.D. 481 (S.D.N.Y. 1973); City of Detroit v. Grinnell Corp., 356 F. Supp. 1380 (S.D.N.Y. 1972), affd, 495 F.2d 448 (2d Cir. 1974); Zerkle v. ClevelandCliffs Iron Co., 52 F.R.D. 151 (S.D.N.Y. 1971).

110. See, eg., Protective Comm. v. Anderson, 390 U.S..414, 424-25 (1968); In re Corrugated Container Antitrust Litig., 643 F.2d 195, 212 (5th Cir. 1981); In re Traffic Executive Ass'n, 627 F.2d 631, 633 (2d Cir. 1980); Shiensky v. Dorsey, 574 F.2d 131, 147 (3d Cir. 1978); City of Detroit v. Grinnell Corp., 495 F.2d 448, 455 (2d Cir. 1974); West Virginia v. Chas. Pfizer \& Co., 440 F.2d 1079, 1085 (2d Cir.), cert. denied, 404 U.S. 871 (1971); Percodani v. Riker-Maxson Corp., 50 F.R.D. 473 (S.D.N.Y. 1970); Haudek, supra note 48, at 773.

111. See generally Protective Comm. v. Anderson, 390 U.S. 414, 424-25 (1968); In re Corrugated Container Antitrust Litig., 643 F.2d 195, 212 (5th Cir. 1981); In re Traffic Executives Ass'n, 627 F.2d 631, 633 (2d Cir. 1980); Shlensky y. Dorsey, 574 F.2d 131, 147 (3d Cir. 1978); City of Detroit v. Grinnell Corp., 495 F.2d 448, 455 (2d Cir. 1974); West Virginia v. Chas. Pfizer \& Co., 440 F.2d 1079, 1085 (2d Cir.), cert. denied, 404 U.S. 871 (1971); Percodani v. Riker-Maxson Corp., 50 F.R.D. 473,478 (S.D.N.Y. 1970); Haudek, supra note 48, at 773.

The ALI Principles of Corporate Governance and Structure set forth the following criteria for the court.

In evaluating a proposed settlement, the court shall place primary emphasis on the following factors: (1) the size of the best possible net recovery and, if calculable, the probable net recovery at trial, discounted in each case by the risk to the corporation of an adverse judgment, in relation to the net value of the proposed settlement; (2) the impact of delay on the value of the recovery if litigation were to continue; (3) the value of any corrective measures required by the settlement or undertaken as a result of litigation: (4) the deterrent impact of the settlement with respect to the conduct in question; (5) the adverse effects, if any, of the continuation of the litigation on the corporation; and (6) the availability of other plaintiffs to intervene and prosecute the action, or a portion thereof, in a superior fashion. The proponents of a settlement shall bear the burden of proving that it is in the best imterests of the corporation and its shareliolders.

Principles of Corporate Governance and Structure: Restatement and RecommendanIONS 8 7.04(b) (Tent. Draft No. 1, 1982) [hereinafter cited as CORPORATE GovernanCE].

112. See, eg., In re Corrugated Container Antitrust Litig., 643 F.2d 195, 212-16 (5th Cir. 1981), cert. denied, 102 S. C. 2283 (1982); Newman v. Stein, 464 F.2d 689, 693 (2d Cir.), cert. denied, 409 U.S. 1039 (1972); City of Detroit v. Grinnell Corp., 356 F. Supp. 1380, 1385-87 (S.D.N.Y. 1972), affd, 495 F.2d 448 (2d Cir. 1974). 
are viable, the court then establishes a range of possible recovery that the corporation could realize at trial and compares this to the proposed settlement terms. ${ }^{113}$ If the plaintiffs are very likely to succeed, it should be difficult, if not impossible, for a party to justify a settlement that falls below the probable range of recovery; 114 if the cause of action seems relatively frivolous, however, the court may approve a much smaller settlement. 115

Some courts have stated that in the settlement process, a court must not substitute its own business judgment for that of the parties. ${ }^{116}$ This is an unrealistic admomition; to evaluate the merits of proposed settlement terms, the court must exercise its own legal and business judgment. ${ }^{117}$ For instance, in approving the settlement proposal, the district court in Clark evaluated the factual and legal hurdles that the plaintiffs would have faced at trial; the complexity and length of a trial; the costs of trial to Booth, Inc.; the possible loss to Booth, Inc. of indemnification costs for those defendants that had waived indemnification in the settlement proposal; and the possible conflicts of interest between the attorneys on both sides that could have resulted ultimately in the disqualification of some attorneys, postponeinent of the trial, or

Among the factors considered by courts are the complexity and the probable expense and duration of the litigation; the costs to the corporation of indemnifying the defendant directors; the difficulty of collecting a judgment; and the litigation's burden on the court. See generally Protec. tive Comm. v. Anderson, 390 U.S. 414, 424-25 (1968); Shlensky v. Dorsey, 574 F.2d 131, 147 (3d Cir. 1978); Grunin v. International House of Pancakes, 513 F.2d 114, 123-25 (8th Cir. 1975); In re Montgomery County Real Estate Antitrust Litig., 83 F.R.D. 305, 315-18 (D. Md. 1975); Clark I, 79 F.R.D. at 648-52; City of Detroit v. Grinnell Corp, 356 F. Supp. 1380, 1385-89 (S.D.N.Y. 1972), affd, 495 F.2d 448 (2d Cir. 1974); Milstein v. Werner, 57 F.R.D. 515, 524-25 (S.D.N.Y. 1972); see also Note, Factors Considered in Determining the Faimess of a Settlement, 68 Nw. U.L. REv. 1146 (1974).

113. See, eg., City of Detroit v. Grinnell Corp., 495 F.2d 448, 455 (2d Cir. 1974); Clark I, 79 F.R.D. at 651 .

114. Though it seems elementary, courts sonetimes find it necessary to remind litigants that a settlement represents a compromise between the parties: as the quid pro quo for not having to bear the burdens of litigation, plaintiff-stockholders will not obtain the maximum possible recovery for their corporation and the defendants will not have an opportunity to exonerate themselves in court. See, eg., Ellis v. Naval Air Rework Facility, 87 F.R.D. 15, 19 (N.D. Cal. 1980); Percodani v. Riker-Maxson Corp, 50 F.R.D. 473, 477 (S.D.N.Y. 1970).

115. City of Detroit v. Grinnel Corp., 495 F.2d 448, 455 n.2 (2d Cir. 1974).

116. See, e.g., McDonald v. Chicago Milwaukee Corp., 565 F.2d 416, 426-27 (7th Cir. 1977) (citing United Founders Life Ins. Co. v. Consumers Nat'1 Life Ins. Co., 447 F.2d 647, 655 (7th Cir. 1971)).

117. 'Tt is perhaps the basis of the view denying a free hand to an independent directorate that a court may not safely conclude, in the absence of becoming a third party to the compromise.... [citation omitted] that the directors are indeed acting independently and that a settlement lacks all taint." Birnbaum v. Birrell, 17 F.R.D. 409, 412 (S.D.N.Y. 1955). See supra notes 86-93 and ac. companying text. 
dismissal of the case. ${ }^{118}$ Thus, although a court's approval of a settleinent proposal may implicitly vindicate the business judgment of the parties, ${ }^{119}$ the numerous factors it inust consider in evaluating the merits of a settlement proposal inake it necessary for the court to exercise its own business and legal judgment. ${ }^{120}$ By exercising its judgment and undertaking a stringent review of the settlement's terms, the court protects the corporation from unfair dealing by any party to the suit.

\section{The Search for a Parity of Reasoning}

The Clark decision presents the question whether the potential for fraud or collusion in settlement negotiations caused by the lack of an independent board of directors should preclude approval of an otherwise fair settlement. In demand requirement cases, a similar potential for fraud or collusion prevents the board froin exercising its usual role in managing the affairs of the corporation. ${ }^{121}$ An examination of the two types of cases, however, demonstrates that the "parity of reasoning" on which the Clark court relied does not exist.

In demand requireinent cases, the court balances the corporation's right to obtain judicial redress for its alleged injuries in the face of board opposition against the board's right to manage. Neither right is absolute. If the board is independent, the court requires the deinand and defers to the board's decision regardless of the suit's inerits, because an independent board is presumed to have made a fair evaluation of the suit.122 If the board is not independent, however, the court excuses the demand requireinent and will not defer to the board's opinion of the suit's merits because the board, lacking independence, is presuned to be unable to provide unbiased guidance for the corporation. ${ }^{123}$ If the court were to bind the corporation to the decision

118. See Clark I, 79 F.R.D. at 650-53, 656-57; see also Clark v. Lomas \& Nettleton Fin. Corp.; 79 F.R.D. 658 (N.D. Tex. 1978) (denying motion to disqualify corporate counsel based on alleged conflict of interest). The district court in Clark estimated that Booth, mc. would have incurred additional costs of $\$ 500,000$ to $\$ 900,000$ had the claims been litigated. See Clark I, 79 F.R.D. at $652,656$.

119. When a court rejects proposed settlement terms, it rejects the business judgment of the parties. The court may also indicate to the parties what terms it might find acceptable, and it could then be argued that the court has thereby substituted its own business judgment for that of the parties. However, before the recommended terms can be formally proposed to the court, the parties must return to the negotiating table and exercise their own busmess judgment to determine whether it is to their advantage to adopt the recommendation. Thus, the corporation and the defendants retain their power to determine the specifics of the settlement proposal.

120. See supre notes $110-18$ and accompanying text.

121. See supra notes $63-67$ and accompanying text.

122. See supro notes $59-62$ and accompanying text.

123. See supro notes $63-68$ and accompanying text. 
of a non-independent board, it would risk the loss of a viable corporate cause of action. ${ }^{124}$ Allowing the suit to proceed, however, risks the continuation of a strike suit. 125

Recognizing this risk, courts allow the corporation to protect itself against strike suits by creating a special litigation committee that can recommend dismissal of the suit even if the full board cannot. ${ }^{126}$ The committee is ostensibly independent, and it is empowered to study the suit and to recommend its continuation or dismissal. The board regains its right to manage the corporation by using the committee to reestablish its independence, which courts regard as a guarantee that the board will fulfill its statutory duty to manage the corporation in an unbiased manner. Recognizing, however, that the directors' inherent pro-defendant sympathies may render their technical independence an inadequate safeguard, courts following Zapata Corp. v. Maldonado 127 may also perform an independent analysis of the committee's decision to eusure that the corporation is treated fairly. ${ }^{128}$

Even though courts in settlement cases must balance the same considerations that control in demand requirement cases, settlement cases nevertheless differ from demand cases. In demand cases, if the court defers to the decision of a biased board, the suit is dismissed, and the corporation receives nothing. In settlement cases, however, the board cannot completely frustrate the corporation's rights because the corporation will receive fair recompense for its alleged mjuries. Furthermore, because the court's ouly alternative in demand cases is to dismiss the suit, the court assumes that the plaintiff filed the suit in good faith and allows the plaintiff to maintain the suit derivatively once the demand has been excused. In many cases, however, the corporation's legal claims are frivolous and the plaintiff or his attorney may have filed the suit primarily for personal gain; thus, the corporation gains nothing and inay lose a great deal from the continued maintenance of the suit. 129 In such a situation, a board of directors should not be precluded froin settling the case with the defendants on behalf of the cor-

124. Technically, another plaintiff could file suit and again demand that the board pursue the claim on the corporation's behalf. The board, however, would simply reject the demand again.

125. See generally Zapata Corp. v. Maldonado, 430 A.2d 779, 784-85, 788 (Del. 1981).

126. See supra notes 71-75 and accompanying text.

127. 430 A.2d 779 (Del 1981).

128. See supra notes 76-80 and accompanying text. Although commentators have questioned whether Zapata significantly increases the level of the court's review, see Cox, supra note 61, at 1007-11, Zapara stands at least for the proposition that the SLC cannot be completely trusted to protect the corporation.

129. In Clark $I$, the district court noted its suspicions that the plaintiff sought personal gain mure wan it sought to protect the corporation. See 79 F.R.D. at 652, 656. 
poration simply because the board is not independent. By refusing to allow a non-independent board to act, the court inay prevent a fair settlement and prolong an unfair suit.

Of course, the board may be able to regain its independence by appointing a special settlement committee (SSC) or, should that prove impossible, by requesting that the court appoint an unbiased panel to settle the case. ${ }^{130}$ The Clark court alluded to this possibility in a footnote to its opinion, ${ }^{131}$ and the proposed Principles of Corporate Governance and Structure, now before the ALI ${ }^{132}$ endorse such a course of action. Although it might seem desirable to require an independent SSC where the board itself is not independent, closer analysis suggests that such a requirement would unnecessarily infringe on the board's statutory duty to manage the corporation.

The requirement of an SSC elevates form over substance because the justification for appointing an SLC in demand cases has no analogue in settlement cases. In demand cases, the SLC protects the corporation against the influence of biased directors. ${ }^{133}$ In settlement cases, however, such protection is available without the appointment of an SSC. First, under the pre-Clark test, courts automatically reject any settlement tainted by collusion. ${ }^{134}$ This rejection prevents a board from, in effect, settling the case with itself. Second, to guard against actual and structural bias, the court conducts its own in-depth review of

130. See CoRPORATE GOVERNANCE, supra note $111,8 \$ 7.04-7.05$.

131. See Clark II, 625 F.2d at 54 n.6 ("this case [does not] present any issue respecting whether . . . a duly constituted executive committee could have achieved what the directors unsuccessfully attempted").

Based on the Clark court's holding and the facts of the case, it is doubtful that the board of Booth, Inc. could have appointed an SSC or SLC with sufficient independence to satisfy the court. First, the Clark court's disapproving reference to "structural bias," 625 F.2d at 53, indicates that the court would not have accepted such bias in an SSC. Second, the board of Booth, Inc. that attempted to settle the suit consisted primarily of outsiders who were appointed subsequent to the transaction that gave rise to the suit. See Clark I, 79 F.R.D. at 619; supra note 36. Until Clark, the Booth board would have been sufficiently independent to coinprise an SLC. See supra notes. 69-74 and accompanying text; $\mathscr{~}$. Note, Business Judgment Rule, supra note 13, at 619-22.

132. See Corporate GovernanCE, supra note $111, \$ 87.04,7.05$. The proposal before the ALI cites the Clark case in support of the SSC requirement, see id. at 373; however, the proposal does not address the problems underlying Clark.

133. The adequacy of this protection is suspect; a lack of confidence in the independence of SLCs prompted the Delaware Supreme Court to unandate review of their decisions in Zapara. "[W] hen examining the . . . [SLC] mechanism, potentials for abuse must be recognized." 430 A.2d at 785. See supra notes 76-80 and accompanying text. Even though other jurisdictions have not yet followed Zapasa, its analysis is a step in the right direction. See, e.g., Cox, supra note 61, at 982-85. But see Joy v. North, 692 F.2d 880 (2d Cir. 1982). Furthermore, there is no reason to believe that SSCs will be freer of structural bias than SLCs.

134. See supre notes 97,106 and accompanying text. 
the proposed settlement. ${ }^{135}$ The court usually has extensive knowledge of the case from its supervision of discovery. ${ }^{136}$ In addition, all interested parties may present their case for or against the proposed settleinent, ${ }^{137}$ and all parties have had the opportunity to conduct discovery and to gather facts in support of their arguments. ${ }^{138}$ The court may also weigh the independence or bias of the parties in reaching its determination of the validity of their arguments, and, should the court find the settlement unfair, it can guide the parties toward an acceptable agreement. ${ }^{139}$ Thus, the court can effectively evaluate the settlement

135. See supra notes $81-95,109-20$ and accompanying text.

136. For example, in Clark $I$ the district court noted its familiarity with the case, see supra note 91 , and remarked that the "history of this case has paralleled the creation of the universe." 79 F.R.D. at 643.

137. If no one contests the settlement, the-court will not be able to evaluate the settlement as thoroughly, see infra note 138 , and if all parties were engaged in questionable conduct, the coun might madvertantly approve an unfair settlement. Although this may be a plausible argument for requiring an independent board, the Clark case did not present such a situation, the court did not base its holding on the need to encourage challenges to proposed settlements, and most courts are not naive when acting as guardian of the corporation's interest. Furthermore, if the courts decided to require an independent board only when both parties approved the settlement, the parties might simply settle out of court under Wolf $v$. Barkes. See infra notes $141-42$ and accompanying text. Also, if settleinent ultimately proved reasonable, having required independence would result in a deadweight economic loss to the corporation.

138. [In cases] where there are objectors, the court is aided in its task; the proponents can

be expected to present evidence and arguments suggesting that the settleinents are within

a 'range of reasonableness' and the objectors will do the same for the contrary position.

By weighing the competing evidence and evaluating the legal argumeuts, we think the

court should be able to reach a just conclusion.

In re Corrugated Container Antitrust Litig., 643 F.2d 195, 213 (5th Cir. 1981), cert. denied, 102 S. Ct. 2283 (1982).

139. One might contend that an independent board would reach a better settlement for the corporation than a non-independent board, although both settlements might be fair. This contention lacks merit. As stated by the Fifth Circuit in In re Corrugated Container Antitrust Litig. " "ii]f the terms themselves are fair, reasonable and adequate, the district cour may . . . assume that they were negotiated by competent and adequate counsel; in such cases, whether another team of negotiators might have accomplished a better settlement is a matter equally comprised of conjecture and irrelevance." 643 F.2d at 212; see also Grunin v. International House of Pancakes, 513 F.2d 114, $125 \mathrm{n.9}$ (8th Cir. 1975). Furthermore, judicial review of settlement proposals is not and should not be confined to a mere determination of whether or not the corporation's board is independent. See Bimbaum v. Birrell, 17 F.R.D. 409, 410 (S.D.N.Y. 1955). But of. Susquehanna Corp. v. Korholz, 84 F.R.D. 316, 321 (N.D. Ill. 1979). See supra note 104. The court must go beyond the independence issue in order to determine whether a proposed compromise is in fact free from fraud and collusion, and is fair, adequate and reasonable. See supra notes 94-120 and accompanying text. Thus, a court should not assume that the fact that a board is imdependent necessarily means that the settlement negotiations were free from fraud or collusion, or that the settlement terms are fair, adequate and reasonable to the corporation. Nor should a court assume, as did the Clark $I I$ court, that the fact that a board is not independent necessarily means that the negotiations were fraudulent and collusive or that the terms are unfair, imadequate or unreasonable. To make any such assumptions "represent[s] the abdication of judicial discretion rather than its informed exercise." McDonald v. Chicago Milwaukee Corp., 565 F.2d 416, 422 (7th Cir. 1977). 
and advise the parties in a manner impossible in demand-requirement cases, which are decided on the bare allegations of the complaint. ${ }^{140}$

Other considerations suggest that requiring the board to establish independence may be counterproductive as well as-unnecessary. If the board cannot obtain an in-court settlement unless it reestablishes its independence, either by requiring some of its members to resign and allowing new disinterested persons to take their place or by requesting the court to appoint a special panel, the board may simply choose to settle out of court with the plaintiff as allowed by Wolf $v$. Barkes. ${ }^{141}$ This alternative may be less costly and more attractive than initiating a mass resignation or transferring the power to settle the suit to a group of strangers. By requiring an independent board, the Clark court may simply have given derivative plaintiffs added leverage in pursuing their own personal gain by demanding out of court settlements. ${ }^{142}$ Thus, the concern for fairness to the corporation that justifies the requirement of an independent board in demand cases may be totally frustrated by requiring an imdependent board in settlement cases.

\section{ConClusion}

In asserting the existence of a parity of reasoning between dennand requirement cases and settlement cases, the Clark court ignored the distinctions between those cases. Although the Clark court correctly suspected the motivations of corporate boards of directors, ${ }^{143}$ the solution it proposes unnecessarily diminislies the availability of in-court settlements pursuant to Rule 23.1 while providing little, if any, protection to corporations. Although the court sought to protect the corporation's interests, its decision may have exactly the opposite effect by encouraging out-of-court settlements that principally benefit plaintiffs

140. See supra notes $66-67$ and accompanying text.

141. 348 F.2d 994 (2d Cir.), cert. denied, 382 U.S. 941 (1965). Encouraging such results is undesirable, and it is doubtful that the inherent limitation of $W$ olf that an out of court settlement offers no res judicata effect, see id at 996-97; Cox, supra note 61, at 970-71, will be sufficient to prevent boards from using out of court settlements to avoid the independence requirement of Clark.

142. This raises substantial possibilities for abuse in the form of questionable dealings by plaintiff' attorneys. Courts have always been suspicious of cases in which the real party in interest seems to be lawyer. For instance, in class actions, courts frown on the sunultaneous negotiation of attorney's fees and the amount of damages or other remedies. See, eg., Mendoza v. United States, 623 F.2d 1338, 1352 (9th Cir. 1980); Prandini v. National Tea Co., 557 F.2d 1015, 1021 n.7 (3d Cir. 1977). The Mendoza court stated:

We cannot indiscriminately assume, without more, that the amount of fees have no influence on the ultimate settlement obtained for the class when, along with the substantive remedy issues, it is an active element of negotiation. [citation omitted]

623 F.2d at 1351 .

143. "Clark questions director impartiality in any suit against a current control person." Cox, supra note 61 , at 1002 . 
or plaintiffs' counsel. To avoid such a result, the Courts of Appeals for the Fifth and Eleventh ${ }^{144}$ Circuits should overrule Clark at their earliest opportunity.

Kenneth W. Kossoff

144. See Bonner v. City of Prichard, 661 F.2d 1206, 1207 (11th Cir. 1981) (holding that decisions of the former Fifth Circuit issued prior to October 1, 1981 shall be binding as precedent in the Eleventh Circuit). 